\title{
CARDIAC CHANGES IN RHEUMATOID ARTHRITIS
}

\author{
BY

\begin{abstract}
NILS EGELIUS, OLLE GÖHLE, ERIC JONSSON, AND FREDRIK WAHLGREN
\end{abstract} \\ From the Södersjukhuset, Stockholm
}

(RECEIVED FOR PUBLICATION OCTOBER 8, 1954)

The present investigation represents a continuation of inquiries by Jonsson, Berglund, Göhle, Ejrup, and Friedman (1952) first reported in 1949 at the Seventh International Congress of Rheumatology, New York.

\section{Previous Investigations}

Pathological Studies.-In a series of 25 autopsies of cases of rheumatoid arthritis, Baggenstoss and Rosenberg (1941) found "lesions of the type produced by rheumatic fever" in fourteen, though there was a history of rheumatic fever in only two; they concluded that "chronic infectious arthritis" and rheumatic fever might be in some way related. Fingerman and Andrus (1943) reported positive findings in nineteen of 61 cases, only two of which had a history of rheumatic fever. Reports have also been made by Bayles (1943), Bennett (1943), Young and Schwedel (1944), Rosenberg and others (1944), Clark and Bauer (1948), Graef and others (1949), Snorrason (1950), Bywaters (1950), and Sokoloff (1953). The percentages of rheumatic cardiac changes recorded by these authors varies a great deal, but 117 (27 per cent.) of the total of 439 cases assembled from these reports, revealed signs of rheumatic cardiac disease, and 133 (30 per cent.) signs of pericardial changes. Table I shows the nature of cardiac lesions in 288 of the cases reported in the literature, but in some reports the data were too incomplete for classification.
Clinical Studies.-In the majority of clinical investigations cardiac lesions were found much less frequently than in the pathological studies.

However, Kahlmeter (1934) found electrocardiographic changes in up to 27 per cent. of cases of "secondary chronic polyarthritis", and in up to 12 per cent. of cases of "primary chronic poly-arthritis"; in a control series, pathological electrocardiograms were obtained in only $2 \cdot 6$ per cent.

Dawson and Tyson (1936) found cardiac changes of a rheumatic nature in 7 per cent. of 100 cases. Monroe (1939) noted rheumatic valvular defects in 4 per cent. of 267 patients. Feiring (1945) reported pathological cardiac findings in 29 per cent. of 27 cases, but these included two with a history of rheumatic fever and another two in which that diagnosis seemed probable. Rogen (1947) reported positive cardiac findings in only 3 per cent. of 33 cases. Jonsson and others (1952) examined (by radiography, electrocardiography, hypoxaemia test, auscultation, and phonocardiography) 37 cases of rheumatoid arthritis and 37 controls; positive cardiac findings amounted to eleven cases ( 30 per cent.) in the rheumatoid group, and three $(8 \cdot 1$ per cent.) in the control group.

Gil (1949) recorded endomyocardiac lesions in 5.5 per cent. of 360 cases; apart from a greater frequency of aortic defects, the symptoms were of the same type as those seen in rheumatic fever, and $3 \cdot 3$ per cent. showed

TABLE I

LOCALIZATION OF PATHO-ANATOMICAL CARDIAC CHANGES IN 288 CASES OF RHEUMATOID ARTHRITIS

\begin{tabular}{|c|c|c|c|c|c|c|c|c|}
\hline \multirow{2}{*}{\multicolumn{3}{|c|}{ Author }} & \multirow[b]{2}{*}{ Date } & \multirow{2}{*}{$\begin{array}{c}\text { Number } \\
\text { of } \\
\text { Cases }\end{array}$} & \multicolumn{4}{|c|}{ Cardiac Lesions } \\
\hline & & & & & $\begin{array}{c}\text { Rheumatoid } \\
\text { Cardiac } \\
\text { Changes }\end{array}$ & $\begin{array}{l}\text { Valvular } \\
\text { Changes }\end{array}$ & $\begin{array}{c}\text { Myocardial } \\
\text { and Vascular } \\
\text { Changes }\end{array}$ & Pericarditis \\
\hline \multicolumn{3}{|c|}{ Baggenstoss and Rosenberg } & 1941 & 25 & 14 & 11 & 12 & 5 \\
\hline \multicolumn{2}{|l|}{ Fingerman and Andrus } & $\cdots$ & 1943 & 61 & 19 & 19 & 2 & 7 \\
\hline Bayles $\quad \ldots \quad \ldots$ & . & $\ldots$ & 1943 & 23 & 6 & 6 & 3 & 4 \\
\hline Young and Schwedel & . & $\cdots$ & 1944 & 38 & 25 & 24 & 4 & 19 \\
\hline Rosenberg and others. & $\cdots$ & $\ldots !$ & 1944 & 30 & $16^{*}$ & 13 & 9 & 5 \\
\hline Clark and Bauer & $\cdots$ & $\cdots !$ & 1948 & 45 & 1 & $?$ & $?$ & 20 \\
\hline Graef and others & $\cdots$ & $\cdots$ & 1949 & 66 & 26 & 24 & $7 ?$ & 33 \\
\hline
\end{tabular}

* Data regarding the exact nature of the rheumatic cardiac changes are lacking in two of these cases. 


\begin{tabular}{|c|c|c|c|c|c|c|c|}
\hline \multirow[b]{2}{*}{$\begin{array}{l}\text { Case } \\
\text { No. }\end{array}$} & \multirow[b]{2}{*}{ Sex } & \multicolumn{5}{|c|}{ Clinical Data } & \multirow[b]{2}{*}{ Cause of Death } \\
\hline & & $\begin{array}{l}\text { Age } \\
\text { (yrs) }\end{array}$ & $\begin{array}{c}\text { Duration } \\
\text { of } \\
\begin{array}{c}\text { Disease } \\
\text { (yrs) }\end{array}\end{array}$ & Heart Symptoms & \multicolumn{2}{|c|}{ Other Disease } & \\
\hline 1 & $\mathbf{M}$ & 58 & 24 & 0 & \multicolumn{3}{|c|}{$\begin{array}{l}\text { Encephalomalacia } \\
\text { Bronchopneumonia }\end{array}$} \\
\hline 2 & $F$ & 65 & 13 & 0 & Chronic nephritis & & Uraemia \\
\hline 3 & $\bar{F}$ & 52 & 14 & 0 & \multicolumn{3}{|c|}{$\begin{array}{l}\text { Empyema } \\
\text { Brnnchopneumonia } \\
\text { Bronchiectasia }\end{array}$} \\
\hline 4 & $\mathbf{M}$ & 52 & 1 & $\begin{array}{l}\text { Hypertension } \\
\text { Acute pericarditis }\end{array}$ & $\begin{array}{l}\text { Tubercular pulmon } \\
\text { Emphysema }\end{array}$ & ary induration & Acute pericarditis \\
\hline 5 & $\mathbf{M}$ & 71 & 1 & 0 & \multicolumn{3}{|c|}{ Myeloid leukaemia } \\
\hline 6 & $F$ & 68 & 55 & 0 & \multicolumn{3}{|c|}{$\begin{array}{l}\text { Subacute nephritis } \\
\text { Septicaemia (?) }\end{array}$} \\
\hline 7 & $\mathbf{M}$ & 80 & 5 & $\begin{array}{l}\text { Hypertension } \\
\text { Cardionephrosclerosis }\end{array}$ & \multicolumn{3}{|c|}{$\begin{array}{l}\text { Ca. ventriculi }+ \\
\text { Diabetes mellitus }\end{array}$} \\
\hline 8 & $\mathbf{F}$ & 60 & 25 & $\begin{array}{l}\text { Earlier pericarditis } \\
\text { Suspected myocardial infarction }\end{array}$ & \multicolumn{3}{|c|}{$\begin{array}{l}\text { Bronchopneumonia } \\
\text { Pleurit. chr. bilat. }\end{array}$} \\
\hline 9 & $\mathbf{F}$ & 55 & 9 & $\begin{array}{l}\text { Hypertension } \\
\text { E.C.G.: P. pulmonale }\end{array}$ & $\begin{array}{l}\text { Bronchiectasiae } \\
\text { Emphysema }\end{array}$ & & $\begin{array}{l}\text { Cardiac insufficiency } \\
\text { (cor pulmonale) }\end{array}$ \\
\hline 10 & $\mathbf{F}$ & 64 & 7 & $\begin{array}{l}\text { Hypertension } \\
\text { E.C.G.: Myocardial damage }\end{array}$ & Nephrosclerosis & & Encephalomalacia \\
\hline 11 & $\mathbf{F}$ & 72 & 17 & 0 & \multicolumn{3}{|c|}{ Bronchopneumoniae } \\
\hline 12 & $\mathbf{M}$ & 56 & 24 & 0 & \multicolumn{3}{|c|}{$\begin{array}{l}\text { Myeloid leukaemia } \\
\text { Nephrosis }\end{array}$} \\
\hline 13 & $\mathbf{F}$ & 66 & 10 & $\begin{array}{l}\text { Hypertension } \\
\text { E.C.G.: Cardiosclerosis }\end{array}$ & $\begin{array}{l}\text { Arteriosclerosis } \\
\text { Shrivelled kidneys }\end{array}$ & & Cardiosclerosis \\
\hline
\end{tabular}

electrocardiographic changes suggestive of myocardiac lesions. Rosenberg (1949) found pathological cardiac symptoms in 3.4 per cent. of 150 cases as against 2 per cent. in a control series. Bradfield and Hejtmancik (1950) noticed electrocardiographic and radiographic abnormalities in sixteen ( $35 \cdot 8$ per cent.) of 45 cases, but in not more than seven cases were the symptoms pronounced enough to justify a diagnosis of cardiac disease. Rosenberg, Bishop, Weintraub, and Hench (1950), in a clinical investigation of 114 cases of rheumatoid arthritis, 33 cases of ankylosing spondylitis, and a control group of 100 cases of the same age distribution, concluded that cardiac changes were not more frequent in the rheumatoid patients than in the control group. Lucchesi, Lucchesi, and Kneece de Melo (1947) found no sign of cardiac change in fifty patients with rheumatoid arthritis. Rohlin and Sundelin (1952), in 700 cases of rheumatoid arthritis, found, among 500 patients who had neither rheumatic fever nor hypertension, 2 per cent. with pathological lesions and $3 \cdot 2$ per cent. with suspected cardiac involvement; they did not think these percentages exceeded what might be expected in normal subjects.

Sury (1952) found "unquestionable cardiac disease" in 7 per cent. of 109 children; this was rheumatic in four patients (three with mitral stenosis and one with recurrence of acute carditis). Cobb, Anderson, and Bauer (1953) reported that 7 per cent. of deaths among 130 cases of rheumatoid arthritis were caused by valvular heart disease.

\section{Material of Present Survey}

Pathological.-A complete post-mortem examination of the heart was carried out in thirteen cases of typical rheumatoid arthritis, none of which had had rheumatic fever. After a macroscopic routine examination of the heart, specimens for a microscopic examination were obtained as follows:

(1) T-shaped block through the anterior wall of the heart, through the right and left ventricle and the septum.

(2) Longitudinal block through the aortic ring and the septum ventriculorum cordis, the septum membranaceum cordis, and downwards.

(3) Block from the posterior wall of the left ventricle on a level with the posterior papillary muscle.

(4) Block from the right ventricular wall midway between the coronary sulcus and the apex.

(5) Longitudinal block through the left anterior papillary muscle. 
Patho-Anatomical Changes

\begin{tabular}{|c|c|c|c|c|c|}
\hline \multicolumn{5}{|c|}{ Cardiac Changes } & \multirow{3}{*}{ Other } \\
\hline \multicolumn{3}{|c|}{ Certain or Suspected Rheumatic Changes } & \multirow{2}{*}{$\begin{array}{l}\text { Coronary } \\
\text { Sclerosis }\end{array}$} & \multirow{2}{*}{$\begin{array}{l}\text { Myocardial } \\
\text { Fibrosis* }\end{array}$} & \\
\hline alvưfar & \multicolumn{2}{|c|}{ Other } & & & \\
\hline G & 0 & Slight interstitial myocarditis & + & + & $\overline{0}$ \\
\hline $0^{6}$ & 0 & 0 & + & + & Lipomatosis \\
\hline 0 & Acute pericarditis & Acute fibrotic pericarditis & + & + & Hypertrophy \\
\hline 0 & 0 & 0 & + & 0 & Myeloid cells \\
\hline 0 & 0 & 0 & $\div$ & 0 & Lipomatosis \\
\hline 0 & 0 & 0 & + & 0 & $\begin{array}{l}\text { Hypertrophy } \\
\text { Dilatation }\end{array}$ \\
\hline 0 & Subacute fibrotic pericarditis & Subacute fibrotic pericarditis & + & + & $\mathbf{0}$ \\
\hline 0 & Pericardial synechiae & Healed pericarditis & + & + & 0 \\
\hline 0 & Pericardial synechiae & $\begin{array}{l}\text { Chronic pericarditis } \\
\text { Subacute interstitial myocarditis }\end{array}$ & + & $\mathbf{0}$ & 0 \\
\hline 0 & 0 & Healed pericarditis & + & + & Brown atrophy \\
\hline
\end{tabular}

(6) Blocks from the right and left auricular walls in the region of the auricula cordis.

In some instances, parts of other organs were also microscopically examined.

The specimens were kept in a $\mathbf{1 0}$ per cent. formalin solution, embedded in paraffin, and stained with haematoxylin-eosin and haematoxylin-Van Gieson. The thickness of the slides was $10 \mu$. All the microscopic specimens were examined by one of us (F.W.). The results are shown in Table II.

Clinical.-This comprised 100 patients (23 male and 77 female; mean age 43 years) with typical rheumatoid arthritis, as well as a control group of 100 patients, 31 men (mean age 42 years) and 69 women (mean age 41 years). The age distribution was the same in both groups. No case of rheumatoid arthritis of less than 1 year's duration was included, and all cases with a definite or suspected earlier rheumatic fever were excluded. To eliminate cardiac changes originating in cardiosclerosis, patients of more than 60 years of age were avoided, and no case admitted to hospital because of cardiac disease, hypertension, pulmonary infection, diabetes, syphilis, or other disease that might affect the cardiovascular system was included. Cases of anaemia with haemoglobin values below 70 per cent. were also rejected. Of the 100 patients in the control group, 97 had been admitted to hospital and three treated in the out-patients' department for diseases with no significance from a cardiological or rheumatological point of view.

\section{Investigations}

Auscultation.-Only presystolic or diastolic murmurs were noted as pathological. When necessary, phonocardiography was applied to supplement the auscultation. Table III shows that the rheumatoid arthritis group contained only two pathological findings on auscultation, the control group none.

TABLE III

AUSCULTATORY FINDINGS

\begin{tabular}{|c|c|c|c|}
\hline Sounds & & $\begin{array}{c}\text { Rheumatoid } \\
\text { Arthritis }\end{array}$ & Controls \\
\hline $\begin{array}{l}\text { Normal heart sounds .. } \\
\text { Soft systolic murmurs . . }\end{array}$ & \begin{tabular}{l|}
$\cdots$ \\
$\cdots$ \\
$\cdots$
\end{tabular} & $\begin{array}{r}46 \\
42 \\
10 \\
2\end{array}$ & $\begin{array}{r}78 \\
17 \\
5 \\
0\end{array}$ \\
\hline Total & .. & 100 & 100 \\
\hline
\end{tabular}


$X$ Ray of the Heart.- Radiography was performed with contrast filling of the oesophagus. Volumes exceeding $500 \mathrm{ml}$. per sq. $\mathrm{m}$. of body surface, and typical configuration changes were recorded as pathological findings. Each group contained one case with pathological findings. These two cases revealed relative heart volumes of $515 \mathrm{ml}$. without configuration defects.

Electrocardiography.-All were examined with extremity leads and chest leads. For technical reasons, only three chest leads were applied to a few patients ( 2 per cent.), but in most instances eleven, and in some up to twenty leads were used.

The following chest leads were used: Nebh leads (D, A, I, M), $\mathrm{CR}_{2}$, IV R, $\mathrm{CR}_{7}, \mathrm{CR}_{8}, \mathrm{CB}_{2}, \mathrm{CF}_{2}$, and IV $F$. In addition, supplementary unipolar extremity leads and/or the chest leads of the Wilson series were applied.

The results were estimated in accordance with the schemata set forth by Grewin (1948). In the present investigation, an electrocardiogram with two or three estimated limit values was regarded as suspect, and one with more than three such values was classified as pathological. The results were as follows:

\section{EXTREMITY LEADS ONLY}

Rheumatic Group, 5 per cent. pathological (one man and four women), 6 per cent. suspect (one man and five women).

Control Group, 4 per cent. pathological (two men and two women), 2 per cent. suspect (one man and one woman).

Chest leads only

Rheumatic Group, none definitely pathological, 2 per cent. suspect (both women).

Control Group, 2 per cent. pathological (both women), 5 per cent. suspect (all women).

EXTREMITY AND CHEST LEADS TOGETHER

Rheumatic Group, 5 per cent. pathological, 7 per cent. suspect.

Control Group, 6 per cent. pathological, 7 per cent. suspect.

The two groups conformed fairly well, and these findings corresponded with those of Rohlin and Sundelin (1952). The changes are summarized in Table IV.

TABLE IV

ELECTROCARDIOGRAPHIC FINDINGS

\begin{tabular}{|c|c|c|c|c|}
\hline Findings & & & $\begin{array}{c}\text { Rheumatoid } \\
\text { Arthritis }\end{array}$ & Controls \\
\hline $\begin{array}{l}\text { Numerous extra systoles } \\
\text { S-T-T changes } \\
\text { Bundle branch block } \\
\text { Pathological P waves }\end{array}$ & $\begin{array}{l}\cdots \\
\cdots \\
\cdots \\
\cdots\end{array}$ & $\begin{array}{l}\cdots \\
\cdots \\
\cdots \\
\cdots\end{array}$ & $\begin{array}{l}3 \\
1 \\
1 \\
-\end{array}$ & $\begin{array}{l}-2 \\
1 \\
1 \\
2\end{array}$ \\
\hline
\end{tabular}

Hypoxaemia Test.-This was performed by the administration of 9 per cent. oxygen for 10 minutes. In judging the tests, the same criteria were applied as those used at the heart clinic at the Södersjukhuset in recent years, which represents a further degree of exactitude above the "strict criteria" of Levy and others (1941).

Tables V and VI disclose some peculiarities in the results of this test. In the rheumatoid arthritis group, one man and no less than seven women ( 8 per cent.) were unquestionably positive, and 2 per cent. were suspect (one man and one woman); in the control group only 4 per cent. were positive and 2 per cent. were suspect (one of the latter also had a suspect electrocardiogram).

TABLE V

RESULTS OF HYPOXAEMIA INVESTIGATIONS

\begin{tabular}{|c|c|c|c|c|c|c|}
\hline Test Results & \multicolumn{3}{|c|}{ Positive } & \multicolumn{3}{|c|}{ Suspect } \\
\hline Sex .. $\ldots$ & Male & Female & $\begin{array}{c}\text { Total } \\
\text { per cent. }\end{array}$ & Male & Female & $\begin{array}{c}\text { Total } \\
\text { per cent. }\end{array}$ \\
\hline $\begin{array}{c}\text { Rheumatoid } \\
\text { Arthritis . . }\end{array}$ & 1 & $7^{*}$ & 8 & 1 & $1 *$ & 2 \\
\hline Controls & 0 & 3 & 3 & 1 & 1 & 2 \\
\hline
\end{tabular}

* All had normal electrocardiograms except one female rheumatoid patient and one female control.

TABLE VI

POSITIVE FINDINGS IN RHEUMATOID ARTHRITIS AND CONTROL GROUPS

\begin{tabular}{|c|c|c|c|c|c|c|}
\hline Group & Sex & $\begin{array}{l}\text { Age } \\
\text { (yrs) }\end{array}$ & $\begin{array}{c}\text { Pre- } \\
\text { systolic } \\
\text { Murmur }\end{array}$ & $X$ ray & $\begin{array}{l}\text { Electro- } \\
\text { cardio- } \\
\text { gram }\end{array}$ & $\begin{array}{c}\text { Hypo- } \\
\text { xaemia } \\
\text { Test }\end{array}$ \\
\hline \multirow{15}{*}{$\begin{array}{l}\text { Rheumatoid } \\
\text { Arthritis } \\
\text { (14) }\end{array}$} & $\mathbf{M}$ & 58 & - & - & - & + \\
\hline & $\mathbf{F}$ & 54 & - & - & - & + \\
\hline & $\mathbf{F}$ & 53 & - & - & + & - \\
\hline & $\mathbf{F}$ & 53 & - & - & - & $\rightarrow$ \\
\hline & $\mathbf{M}$ & 50 & - & $\therefore$ & - & - \\
\hline & $\mathbf{F}$ & 48 & - & - & - & $T$ \\
\hline & $\mathbf{F}$ & 44 & - & - & - & + \\
\hline & $\mathbf{F}$ & 44 & - & - & + & - \\
\hline & $\mathbf{M}$ & 43 & . & - & - & - \\
\hline & $\mathbf{F}$ & 42 & - & - & + & - \\
\hline & $\mathbf{M}$ & 39 & - & - & $+t$ & - \\
\hline & $\mathbf{F}$ & 34 & $\cdots$ & - & - & 4 \\
\hline & $\mathbf{F}$ & 33 & - & 一 & - & $\therefore$ \\
\hline & $\mathbf{F}$ & 28 & - & - & + & + \\
\hline & \multicolumn{2}{|c|}{ Total } & 2 & 1 & 5 & 8 \\
\hline \multirow{9}{*}{$\begin{array}{c}\text { Control } \\
\text { (11) }\end{array}$} & $\mathbf{F}$ & 56 & - & - & - & + \\
\hline & $\mathbf{F}$ & 52 & - & - & + & - \\
\hline & $\underset{\mathbf{F}}{\mathbf{M}}$ & 49 & - & 一 & + & $\longrightarrow$ \\
\hline & $\mathbf{M}$ & 41 & - & $\overline{+}$ & 二 & + \\
\hline & $\mathbf{M}$ & 39 & - & - & + & - \\
\hline & $\mathbf{F}$ & 35 & - & - & - & $t$ \\
\hline & $\mathbf{F}$ & 34 & 一 & - & + & - \\
\hline & F & $\begin{array}{l}34 \\
33\end{array}$ & - & E & t & 一 \\
\hline & $\mathbf{F}$ & 12 & - & - & \pm & $\bar{t}$ \\
\hline - & \multicolumn{2}{|c|}{ Total } & 0 & 1 & 6 & 4 \\
\hline
\end{tabular}


The positive findings in all these tests may be summarized as follows:

\begin{tabular}{|c|c|}
\hline & $\begin{array}{c}\text { Presystolic murmur over the } \\
\text { apex . } \quad . . \\
\text { Pathological radiograph of the }\end{array}$ \\
\hline $\begin{array}{l}\text { Rheuma } \\
\text { toid Grot }\end{array}$ & $\begin{array}{l}\text { Pathological radiograph of the } \\
\text { heart .. .. . . } \\
\text { Abnormal electrocardiograms } \\
\text { Positive hypoxaemia test }\end{array}$ \\
\hline
\end{tabular}

* Two cases showed two results each.

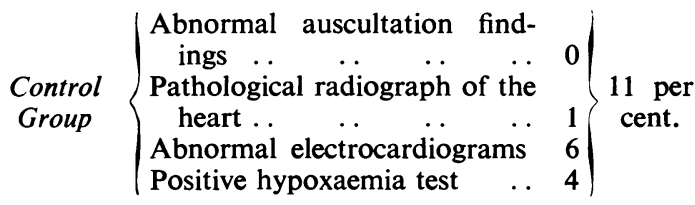

\section{Discussion}

It was not easy to assemble a large number of cases for post-mortem investigation of the occurrence of cardiac lesions in patients with rheumatoid arthritis. Since we excluded cases not available for personal examination, our material is rather small, although we have been considering the present problem from as far back as 1940 .

In the reports of earlier investigators, the percentages of rheumatic heart changes vary considerably, even when patients with rheumatic fever, or other diseases affecting the heart, are excluded. Young and Schwedel (1944), Baggenstoss and Rosenberg (1941), Rosenberg, Baggenstoss, and Hench (1944), and Graef, Hickey, and Altmann (1949) gave high incidence of pathological findings, but Clark and Bauer (1948), Bywaters (1950), and Sokoloff (1953) reported a low incidence. It is possible that due regard was not always paid to senile changes.

The negative results of the present investigation are partly to be explained by the fact that all cases of rheumatic fever were excluded. Pericarditis, healed or not, was ascertained in seven cases, i.e. in more than half the autopsy material. Inflammatory conditions in the lungs and kidneys, which may have contributed to the pericarditis, were noted in some of them, but the frequency of pericarditis in the present material is such that it may, perhaps, be adduced in favour of the contention of Sokoloff and other workers that this condition may be a cardiac manifestation of rheumatoid arthritis. Some of the autopsy cases also showed changes which were interpreted as due to age. Mainland (1953) has summarized factors which have to be borne in mind in any analysis of hospital material, and hospitalization itself implied a selection. In the present investigation the elimination of all cases with cardiac disease as a principal reason for admission may have caused too low a percentage of pathological cardiac findings in the rheumatoid series.

Baggenstoss and Rosenberg (1944) described two cases with cardiac changes markedly suggestive of rheumatic nodules. Sokoloff (1953) discussed the possible occurrence of a specific rheumatoid heart disease, characterized by inflammatory tissue lesions similar to those seen in subcutaneous rheumatic nodules. He studied two such cases, and also referred to similar findings by Graef, Hickey, and Altmann (1949), who described two cases with changes of a nodular type, as well as two cases with changes in the coronary vessels similar to those seen in periarteritis nodosa. Clark and Bauer (1948) and Gruenwald (1948) observed similar nodular changes, but those described by Bevans and others (1954) may be of a different type. Cruickshank (1954) found arteritis, past or present, in eighteen of 72 fatal cases of rheumatoid arthritis; in seven of these, "lesions diagnostic of rheumatic heart disease were also found and the vascular involvement was mainly confined to the heart".

The present authors have noted no such changes, however.

As far as auscultatory, radiological, and (ordinary) electrocardiographic findings are concerned, no difference was noted between the rheumatoid arthritis group and the control group.

On the other hand, the results of the hypoxaemia test showed 8 per cent. positive and 2 per cent. suspect in the rheumatoid group, and only 4 per cent. positive and 2 per cent. suspect in the control group, and most of these were seen in subjects with normal electrocardiograms.*

The age of the female patients with positive hypoxaemia tests and normal electrocardiograms varied in the rheumatoid group of the present material from 33 and 34 to $44,48,53$, and 54 years, and in the control group from 12 to 35,43 , and 56 years. There was thus no difference in age.

One patient treated with cortisone gave a positive hypoxaemia test, but in two other similar cases the result was normal.

It is thus difficult to assess the significance of positive hypoxaemia tests in rheumatoid arthritis. Positive hypoxaemia tests and/or definite electrocardiographic changes occurred with roughly the same frequency in both groups.

$$
\begin{array}{ll}
\text { Rheumatoid arthritis group: } & 7+5=12 \text { per cent. } \\
\text { Control group: } & 4+6=10 \text { per cent. }
\end{array}
$$

* 7 per cent. (one man and six women) of the rheumatoid patients had normal electrocardiograms and pathological hypoxaemia tests, and both the rheumatoid patients with "suspect" hypoxaemia tests had normal electrocardiograms. In the control group all four with pathological and one of the two with suspect hypoxaemia tests had normal electrocardiograms. 
If the "suspect" cases are included, the results are still closely similar:

Rheumatoid arthritis group: $12+10=22$ per cent. Control group: $\quad 10+8=18$ per cent.

It is therefore necessary to seek an explanation of the positive hypoxaemia tests other than that they are due to cardiac affections:

(1) Physical Inactivation.-Prolonged confinement to bed or restricted mobility due to rheumatoid arthritis may lower the tolerance of circulatory exertion so as to preclude a normal adjustment reaction.

None of our patients was in such a condition as to render this explanation probable.

(2) Anaemia.-A pronounced anaemia may cause a positive hypoxaemia test, but the condition is reversible, in so far as rising blood values restore normality.

As previously stated, patients with haemoglobin values below 70 per cent. were eliminated, to avoid this source of error. However, two patients in the rheumatoid group who gave positive hypoxaemia results showed blood values only just above this limit and had periodically displayed lower values; in these two subjects the anaemia may have caused the positive hypoxaemia tests.

(3) Internal Secretion.-Positive hypoxaemia tests may often be noted in women at the age of puberty and in the years immediately following; as well as at the climacteric. These are probably not caused by any cardiac affection; the symptoms may be only temporary, and most likely originate in some vegetative vascular mechanism.

\section{Summary}

The literature on cardiac changes in rheumatoid arthritis is summarized. Most pathological investigations recorded high percentages of cardiac changes of a rheumatic nature, the frequency of such changes in clinical investigations being much lower. Possible explanations of this discrepancy are discussed. In some earlier series, the authors may have failed to pay proper attention to previous rheumatic fever, intercurrent disease of a cardiological character, or changes due to old age.

The present investigation is divided into pathological and clinical sections.

In thirteen post-mortem cases, none manifested any signs of rheumatic endocarditis. Changes, such as those characterized by Sokoloff as indicative of rheumatoid heart disease, were not noted. Signs were found of pericarditis, healed or not, in seven of the thirteen cases, which supports the assumption of certain authors that pericarditis may constitute a cardiac manifestation in rheumatoid arthritis. However, in some of these seven cases other concurrent diseases may have originated the pericarditis.

The clinical series consisted of one hundred cases of rheumatoid arthritis, and one hundred control cases of the same age and sex distribution. No $\frac{O}{\infty}$. case with a history of rheumatic fever or other: disease of cardiological importance was included. The investigation comprised auscultation, phono- 0 cardiography, radiography of the heart, electro-흐 cardiography (with three standard leads and, in $\frac{\bar{s}}{\mathscr{D}}$

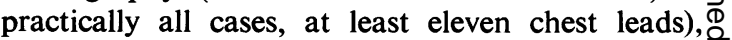
and hypoxaemia tests.

When the positive findings from auscultation, phonocardiography, radiography, and electrocardio-. grams are taken together, they produce a final result $\vec{\omega}$ amounting to 8 per cent. for the rheumatoid groupo and 7 per cent. for the control group.

In the present series, therefore, patients suffering from rheumatoid arthritis did not manifest any: increased frequency of endocardiac or myocardiac ${ }_{-}^{-}$ changes which might be due to the arthritis. In our $\vec{\circ}$ opinion the endocardium and the myocardium are 5 only slightly affected in rheumatoid arthritis, though ${ }_{\overrightarrow{ }}^{-}$ inflammation of the pericardium may, perhaps, be not infrequent.

In support of the idea of a close relationship between rheumatoid arthritis and rheumatic fever, $\mathcal{G}$ several authors have pointed to the high frequency. of cardiac changes of a rheumatic nature which mayo be found in cases of rheumatoid arthritis, implying that these two diseases are manifestations of the same basic illness. But the results of the presento investigation indicate that, when the cardiac findings $\stackrel{\varnothing}{\varnothing}$ only are taken into account, rheumatic fever and $\overrightarrow{\vec{F}}$ rheumatoid arthritis should be regarded as two 3 distinct diseases.

The only significant difference was found in theo results of the hypoxaemia tests; positive results being more frequent in the rheumatoid group.

These examinations were performed at the $X$-Ray Dept. II, to the head of which, W. Magnusson, M.D., special thanks are due.

\section{REFERENCES}

Baggenstoss, A. H., and Rosenberg, E. F. (1941). Arch. intern. Med.N 67,241

-, (1944). Arch. Path. (Chicago), 37, 54

T. B. (1943). Amer. J. med. Sci., 205, 42.

(1943). Ann. intern. Med., 19, 111.

Bevans, M., Nadell, J., Demartini, F., and Ragan, C. (1954). Amer. N I. Med., 16, 197.

Bradfield, J. Y., and Hejtmancik, M. R. (1950). Arch. intern. Med. 86, 1

Bywaters, E. G. L. (1950). Brit. Heart J., 12, 101 Bywaters, E. G. L. (1950). Brit. Heart J., 12, 101.
Clark, W. S., and Bauer, W. (1948). Annals of the Rheumatic
Diseases, 7, 39.

Cobb, S., Anderson, F., and Bauer, W. (1953). New Engl. med. J. 249, 553 .

Cruickshank, B. (1954). Annals of the Rheumatic Diseases, 13, $136 \div$ Dawson, M. H., and Tyson, T. L. (1936). J. Lab. clin. Med., 21, 575응 Feiring, W. (1945). N. Y. St. J. Med., 45, 1855.

Feiring, W. (1945). N.Y. St. J. Med., 45, 1855 .

Gil, J. R. (1949). Abs. in Amer. Heart J., 37, 667.

(1)


Graef, I., Hickey, D. V., and Altmann, V. (1949). Ibid., 37, 635.

Grewin, K. E. (1948). Acta med. Scand., Suppl. 209.

Gruenwald, P. (1948). Arch. Path. (Chicago), 46, 59.

Jonsson, E. Berglund, K., Ejrup, B., Göhle, O., and Friedman, C. E. (1952). In "Rheumatic Diseases", ed. American Rheumatism Association, pp. 68-71. Saunders, Philadelphia.

Kahlmeter, G. (1934). Acta med. Scand., Suppl. 59, p. 611.

Levy, R. L., Patterson, J. E., Clark, T. W., and Bruenn, H. G. (1941). J. Amer. med. Ass., 117, 2113.

Lucchesi, O., Lucchesi, M., and Kneece de Melo, H. (1947). Hospital Rio de J., 32, 699 .' Abs. in Annals of the Rheumatic Diseases,

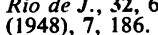

Mainland, D. (1953). Amer. Heart J., 45, 644.

Monroe, R. T. (1939). In "Oxford Medicine", ed. H. A. Christian, vol. 4, pt 2, p. 367 . Oxford University' Press, New York.

Rogen, A. S. (1947). Brit. med. J., 1, 87.

Rohlin, S., and Sundelin, F. (1952). Cardiologia, 21, 470.

Rosenberg, E. F. (1949). Abs. in Amer. Heart J., 37,669.

- Baggenstoss, A. H., and Hench, P. S. (1944). Ann. intern. Med., 20, 903 .

Bishop, L. F., Weintraub, H. J., and Hench, P. S. (1950). Arch. intern. Med., 85, 751.

Smyth, C. J. (1953). In Comroe's "Arthritis and Allied Conditions", Sth ed., ed. J. L. Hollander, p. 103. Lea and Febiger,
Philadelphia.

Snorrason, E. (1950). "Polyarthritis Chronica Primaria". Richter,

Copenhagen.
Sokoloff, L. (1953). Amer. Heart J., 45, 635.

Sury, B. (1952). "Rheumatoid Arthritis in Children. A Clinical Study". Munksgaard, Copenhagen.

Young, D., and Schwedel, J. B. (1944). Amer. Heart J., 28, 1.

\section{Lésions cardiaques dans l'arthrite rhumatismale}

\section{RÉSUMÉ}

On récapitule la littérature sur les lésions cardiaques dans l'arthrite rhumatismale; la plupart des recherches anatomo-pathologiques en révèlent des pourcentages élevés, tandis que les études cliniques donnent des chiffres bien inférieurs. On discute les raisons probables de cette divergence et on croit que dans des observations plus anciennes les auteurs auraient pu ne pas porter attention suffisante sur le rhumatisme articulaire aigu, les maladies intercurrentes de caractère cardiologique ou les lésions séniles.

L'enquête présente se divise en parties anatomopathologique et clinique.

Dans treize cas d'autopsie on ne trouva pas de signes d'endocardite rhumatismale. On ne vit pas de lésions qui, d'après Sokoloff, indiqueraient la maladie rhumatismale du coeur. On trouva, par contre, des signes de péricardite, cicatrisée ou non, dans sept cas sur treize, ce qui vient à l'appui de l'hypothèse de certains auteurs que la péricardite peut constituer une manifestation cardiaque de l'arthrite rhumatismale. Dans certains de ces sept cas, cependant, d'autres maladies concurrentes auraient pu causer la péricardite.

La partie clinique comportait cent cas d'arthrite rhumatismale et cent témoins d'âges et de sexes correspondants. Des cas avec antécédents de rhumatisme articulaire aigu ou de toute autre maladie d'importance cardiologique n'y étaient pas inclus. L'examen comportait l'auscultation, la phonocardiographie, la radiographie du coeur, l'électrocardiographie (avec trois dérivations habituelles et, presque toujours, avec au moins onze dérivations thoraciques) et des épreuves d'hypoxémie.

L'ensemble des résultats positifs d'auscultation, de phonocardiographie, de radiographie et d'électrocardiographie donne le chiffre final de 8 pour cent pour les rhumatisants et de 7 pour cent pour les témoins.
Dans cette série donc, la fréquence des lésions de l'endocarde ou du myocarde chez les rhumatisants n'était pas assez élevée pour qu'on puisse l'attribuer à l'arthrite. A notre avis, dans l'arthrite rhumatismale l'atteinte du myocarde ou de l'endocarde n'est que légère, bien que la péricardite pourrait être plus fréquente.

A l'appui de la conception qu'il y aurait un rapport étroit entre l'arthrite rhumatismale et le rhumatisme articulaire aigu, plusieurs auteurs ont signalé la grande fréquence des lésions cardiaques de nature rhumatismale trouvables dans des cas d'arthrite rhumatismale, signifiant ainsi qu'il s'agirait de manifestations diverses de la même maladie. L'enquête présente indique, toutefois, qu'en tenant compte des résultats cardiologiques seulement, le rhumatisme articulaire aigu et l'arthrite rhumatismale doivent être considérés comme deux maladies distinctes.

La seule différence significative fut trouvée dans les résultats de l'épreuve d'hypoxémie, les positifs étant plus fréquents chez les rhumatisants.

\section{Lesiones cardiacas en la artritis reumatoide}

\section{SUMARIO}

Se resume la literatura sobre las lesiones cardiacas en la artritis reumatoide. La mayoría de las investigaciones anatomo-patológicas revela altos porcentajes de tales lesiones, las investigaciones clínicas dando cifras mucho más bajas. Se discute las razones probables de esta divergencia y se supone que en ciertas estadísticas anteriores los autores no prestaron atención suficiente al reumatismo poliarticular agudo, a las enfermedades intercurrentes de carácter cardiológico o a las lesiones seniles.

La investigación presente se divide en parte anatomopatológica y clínica.

En trece casos de autopsia no encontráronse signos de endocarditis reumática. Tampoco se notaron lesiones que, según Sokoloff, indicarían le enfermedad reumática del corazón. Hubo, en cambio, manifestaciones de pericarditis, activa o curada, en siete de los trece casos, lo que soporta la teoría de ciertos autores según la cual la pericarditis pudiera constituir una manifestación cardiaca de la artritis reumatoide. En algunos de estos siete casos, sin embargo, otras enfermedades concurrentes habrían podido motivar la pericarditis.

La parte clínica comprende cien casos de artritis reumatoide y cien testigos de edades y sexos correspondientes. Casos con antecedentes de reumatismo poliarticular agudo o de otra enfermedad cualquiera de importancia cardiológica no fueron incluídos. La investigación comprendió: auscultación, fonocardiografía, radiografía del corazón, electrocardiografía (con tres derivaciones usuales $y$, virtualmente en todos los casos, con trece derivaciones torácicas) y con reacciones de hypooxemia.

El conjunto de los resultados positivos de auscultación, fonocardiografía, radiografía y electrocardiografía da la cifra final de 8 por ciento para los reumáticos y de 7 por ciento para los testigos.

En esta serie, pues, la frecuencia de las lesiones del endocardio y del miocardio en los reumáticos no fué suficiente para poder atribuirla a la artritis. Nos parece que el compromiso del miocardio o del endocardio en 
la artritis reumatoide es muy leve y el del pericardio, quizás, más frecuente.

En apoyo de la idea de una relación estrecha entre la artritis reumatoide y el reumatismo poliarticular agudo, varios autores señalaron la gran frecuencia de las lesiones cardíacas de naturaleza reumática que se pueden encontrar en los casos de artritis reumatoide, implicando que se trataría de manifestaciones diferentes de la misma enfermedad. La investigación presente indica, sin embargo, que con tener cuenta sólo de los resultados cardiológicos, el reumatismo poliarticular.? agudo y la artritis reumatoide deben considerarse como $\Rightarrow$ enfermedades distintas.

La única diferencia significativa fué encontrada enlos resultados de la reacción de hipooxemia, siendo los positivos más frecuentes en los reumáticos. 